\title{
Evaluasi Pembuatan Prototype Package Tray Biokomposit Serat Tebu- Polypropylene untuk Kebutuhan Interior Mobil
}

\author{
Patrik Permana Putra Wijaya1, Juliana Anggono ${ }^{2 *}$, dan Suwandi Sugondo ${ }^{3}$ \\ 1,2,3 Program Studi Teknik Mesin, Fakultas Teknologi Industri, Universitas Kristen Petra \\ Jl. Siwalankerto 121-131, Surabaya 60236, Indonesia \\ * Penulis korespondensi; E-mail: julianaa@petra.ac.id
}

\begin{abstract}
ABSTRAK
Serat alam yang digunakan untuk pembuatan produk biokomposit dapat mendukung kebutuhan industri akan material yang ringan tapi kuat. Serat tebu merupakan salah satu serat alam yang tersedia banyak di Indonesia. Selain itu riset potensi serat tebu telah sebagai serat penguat matriks polimer telah dilakukan dan penggabungannya pada material plastik dapat meningkatkan sifat mekanisnya. Penelitian ini dilakukan dengan tujuan untuk mengevaluasi pembuatan komposit serat tebu dalam bentuk prototype package tray. Komposisi dan serat tebu disiapkan mengikuti hasil penelitian sebelumnya di mana serat tebu diberi alkali treatment dalam larutan $\mathrm{NaOH} 8 \%$ berat selama 1 jam dalam suhu ruang. Produk hotpress berupa prototype package tray dievaluasi baik dari segi tampilan fisik maupun sifat mekanis dimulai dari tahap pembentukan preform-nya. Sifat mekanis yang diuji adalah uji flexural, dimana nantinya hasil uji akan dibandingkan dengan pengujian sama dari produk pabrik. Hasil uji flexural pada prototype komposit package tray menunjukkan kekuatan flexural 7.4 MPa, di mana nilai kekuatan ini masih dibawah kekuatan flexural produk woodboard dari industri (35.58 MPa). Evaluasi menunjukkan clustering serat tebu, pencampuran PP dan serat tebu yang belum merata pada prototype serta adhesivitas serat tebu dan PP yang rendah ditambah dengan terjebaknya udara pada saat proses hotpress.
\end{abstract}

Kata kunci: Alkali treatment; flexural strength; hotpress; larutan $\mathrm{NaOH}$.

\begin{abstract}
Natural fibers used in the fabrication of biocomposite product can support the need of the industries for lightweight yet strong material. Sugarcane bagasse is one of the available natural fibers in Indonesia. There have been some research done on these bagasse fibers as reinforcement materials for plastics and their incorporation to the matrix has improved its strength. This research aimed to evaluate the fabrication of a car package tray prototype. The composition and the bagasse were prepared in accordance with the previous research in which the bagasse were alkali treated using $\mathrm{NaOH}$ solution of $8 \mathrm{wt} \%$ for one hour at room temperature. The hotpressed prototype was evaluated by its physical outlook and the mechanical property of its preform. The flexural test shows a low flexural strength of the prototype (7.4 MPa) compared to the required strength of the current material (woodboard) used by the industry (35.58 MPa). The evaluation shows the clustering of bagasse fibers, uneven distribution of sugarcane/PP in the structure and low adhesion at the interfacial region between bagasse fibers and $P P$.
\end{abstract}

Keywords: Alkali treatment; flexural strength; hotpress; NaOH solution.

\section{PENDAHULUAN}

Penggunaan material komposit untuk aplikasi pada produk interior mobil (pintu, dashboard, package tray, ceiling liner, sound absorber) adalah solusi bagi industri atas tuntutan untuk memproduksi mobil yang ringan dan hemat bahan bakar. Komposit disusun oleh gabungan dua jenis material, yaitu material penguat dan matriks yang tersedia dalam pilihan plastik, logam, dan keramik. Komposit yang menggunakan serat penguat, dari serat alam disebut sebagai biocomposite. Di negara-negara yang belum memiliki peraturan perlindungan lingkungan seperti yang telah dimiliki negara-negara maju, seperti Amerika Serikat, Eropa, dan Jepang maka mayoritas produsen otomotif masih memilih penggunaan komposit dengan serat sintetis untuk membuat bagian interior mobil. Keunggulan pemakaian biocomposite adalah modulus elastisitas yang relatif tinggi, ringan, kuat, ketersediaan yang luas, mudah terurai di lingkungan dan juga murah [1-3]. 
Telah dilakukan beberapa penelitian pendahuluan yang mempelajari tentang biokomposit menggunakan serat tebu [4-6]. Pada penelitian ini untuk evaluasi prototype digunakan komposit PP dibuat dari serat alam yang berasal dari serat tebu. Dipilihnya serat tebu dikarenakan potensi serat tebu sebagai serat penguat komposit dapat meningkatkan kekuatan plastik PP [6]. Ketersedian lahan pertanian tebu di Indonesia juga luas dengan estimasi 458 ribuan hektar pada tahun 2020 dan hasil produksi tebu mencapai 2,4 juta ton [7]. Selain potensinya, sama seperti kebanyakan serat alam lainnya, serat tebu memiliki keterbatasan dalam hal sifat sensitifnya terhadap kelembaban, kekuatan transversal yang rendah, serta sifatnya bervariasi.

Penelitian pendahuluan dalam bentuk sampel untuk aplikasi package tray telah dilakukan oleh Anggono et al. [5] dimana sampel dibuat dari serat tebu/PP dengan kandungan 20-30 \% berat serat tebu. Pengujian sampel kemudian dibandingkan dengan hasil pengujian sampel produk dari industri yang sudah menggunakan komposit berbahan serbuk kayu dengan campuran PP dan PE (woodboard). Sampel yang dibuat dari $25 \%$ berat serat tebu setelah diberi perlakuan alkali selama 4 jam didapatkan kekuatan flexural sebesar $37.78 \mathrm{MPa}$ dengan gramasi $2566 \mathrm{~g} / \mathrm{m}^{2}$. Hasil tersebut sangat menggembirakan karena telah melampaui spesifikasi material woodboard yang saat ini telah digunakan oleh industri dengan kekuatan flexural 35.58 $\mathrm{MPa}$ dan gramasi $3600 \mathrm{~g} / \mathrm{m}^{2}$ [5]. Berdasarkan hasil riset di atas maka penelitian ini menggunakan komposisi yang sama untuk membuat prototype package tray yang akan dievaluasi. Ada modifikasi yang dilakukan pada pemberian perlakuan alkali pada serat tebu yang digunakan. Modifikasi yang dilakukan adalah pada konsentrasi larutan $\mathrm{NaOH}$ serta lama perendaman. Rujukan atas perubahan tersebut mengacu pada hasil studi sistematis yang dilakukan oleh Bartos et al. (2020) dengan mempelajari pengaruh berbagai konsentrasi larutan $\mathrm{NaOH}$ mulai $1-15 \%$ berat selama 1 jam pada suhu kamar terhadap kekuatan serat tebu yang dihasilkan. Hasil studi menunjukkan kekuatan serat tebu maksimal dapat dicapai pada perendaman menggunakan larutan $\mathrm{NaOH} 8 \%$ berat selama 1 jam pada suhu kamar [8].

Prototype package tray yang dievaluasi dalam penelitian ini adalah mengambil desain produk sama dari salah satu mobil brand Jepang yang diskala 50\% nya. Tujuan evaluasi dalam penelitian ini adalah untuk memberikan perhatian pada fabricability prototype melalui proses hotpress dengan mencermati sifat fisik maupun mekanik prototype yang dimaksud. Sifat fisik diperhatikan dari tampilan visual, keseragaman tebal serta gramasi; sedangkan sifat mekanis diperoleh dari pengujian kekuatan flexural dari sampel prototype. Hasil evaluasi menjadi masukan untuk mendata kesulitan dan kendala proses fabrikasi melalui hotpress untuk mendapatkan solusi perbaikan dimulai dari proses persiapan bahan baku, preform hingga proses hotpress pembentuk produk akhir.

\section{METODE}

\section{Persiapan Material}

Serat tebu yang digunakan pada penelitian ini didapatkan dari ampas tebu hasil gilingan Pabrik Gula Candi Baru, Sidoarjo. Serat Tebu yang didapatkan dinetralisasi dengan merendamnya dalam larutan ethanol $70 \%$ selama 1 jam. Netralisasi ini dilakukan dengan maksud untuk mematikan bakteri untuk mencegah pembusukan ampas. Proses kemudian dilanjutkan pengeringan ampas tebu dengan dianginkan di udara terbuka. Proses selanjutnya adalah proses alkali treatment dimana ampas tebu direndam pada larutan $\mathrm{NaOH} 8 \%$ berat selama 1 jam. Serat tebu kemudian dicuci bersih menggunakan air beberapa kali hingga $\mathrm{pH}$ air cucian menjadi $\mathrm{pH}$ 7. Proses pengeringan ampas tebu kemudian dilakukan dalam oven Memmert pada suhu $80^{\circ} \mathrm{C}$ selama 48 jam.

Selain ampas tebu, disiapkan pula plastik PP sebagai bahan matriks yang diperoleh dari PT. Classic Prima Carpet Industries dalam bentuk serat. Serat PP disiapkan dalam bentuk serat pendek dengan panjang kurang lebih $1 \mathrm{~cm}$.

Serat tebu dan PP yang telah siap kemudian dicampur secara manual. Karena karakteristik kedua bahan yang sulit bercampur karena serat tebu yang menggumpal dan serat PP yang ringan maka proses pencampuran yang paling dimungkinkan adalah dengan tangan untuk memastikan kedua bahan telah tercampur secara homogen. Pencampuran serat tebu dan PP dimaksudkan untuk mendapatkan rasio \% berat serat tebu terhadap PP adalah 25/75. Untuk membuat satu prototype dengan desain yang dimaksud dibutuhkan berat total bahan $200 \mathrm{~g}$. Untuk memastikan keseragaman komposisi pada semua bagian prototype maka area prototype dibagi menjadi 5 bagian, dimana masing-masing bagian tersebut menerima berat campuran@ 40 g dengan berat serat tebu $10 \mathrm{~g}$ dan PP $30 \mathrm{~g}$.

\section{Hotpress Tahap I - Pembentukan Preform}

Preform yang dimaksud adalah berbentuk lembaran panel datar berukuran $25 \mathrm{~cm}$ x $30 \mathrm{~cm}$ x 5 $\mathrm{cm}$. Preform ini dibentuk dengan mesin hotpress menjadi produk setengah jadi dengan tujuan untuk memudahkan handling (meliputi pemindahan, peletakkan, dan membalik) bahan sebelum dipress 
menjadi bentuk desain prototype. Pada tahap awal campuran yang sudah dipersiapkan diletakkan diantara dua lembar aluminium foil. Campuran tersebut kemudian diletakkan di atas mould mesin hotpress bawah, setelah itu dilakukan hotpress dengan suhu $150^{\circ} \mathrm{C}$ dan tekanan $104 \mathrm{kPa}$.Total waktu yang dibutuhkan untuk menurunkan mould atas untuk menekan mould bawah adalah 1 menit. Setelah itu tekanan dinaikkan perlahan-lahan dengan total waktu 1 menit. Kemudian tekanan dan suhu ditahan selama 3 menit pada tekanan 104 $\mathrm{kPa}$. Setelah proses hotpress selesai, suhu preform dibiarkan turun hingga $80^{\circ} \mathrm{C}$ untuk menghindari lembaran preform berubah bentuk. Setelah suhu turun, preform dikeluarkan.

\section{Hotpress Tahap II - Pembentukan Prototype}

Proses hotpress untuk pembentukan prototype dilakukan dengan prosedur yang sama dengan pembuatan preform. Hal yang membedakan adalah pada parameter suhu proses dimana hotpress prototype parameter yang digunakan adalah suhu $190^{\circ} \mathrm{C}$

\section{Karakterisasi Sampel}

Sifat mekanis yang diujikan pada sampel adalah uji flexural terkait dengan kebutuhan aplikasi dan fungsinya sebagai package tray yang menanggung beban dan membutuhkan kelenturan. Komparasi kekuatan flexural dibandingkan dengan sifat sama yang diperoleh dari material woodboard yang merupakan existing material dari industri interior mobil. Pengujian flexural dilakukan dengan metode three point bending test berdasarkan ASTM D790-17. Pengujian dilakukan di Sentra Teknologi Polimer di Tangerang menggunakan mesin Shimadzu AG-X plus dengan kapasitas $50 \mathrm{kN}$ dengan kecepatan tekan $1.476-2.210 \mathrm{~mm} /$ menit.

Sebelum sampel diuji flexural, dilakukan pengukuran dimensi panjang, lebar, dan tebal. Pengukuran tebal dilakukan pada lima lokasi berbeda pada sampel, masing-masing berjarak $20 \mathrm{~mm}$ dari titik pengukuran berikutnya. Selain pengukuran dimensi sampel, tiap sampel juga ditimbang untuk menghitung gramasi (areal density). Mikrostruktur pada permukaan patahan sampel uji flexural juga dievaluasi menggunakan scanning electron microscop (SEM) merk untuk mengevaluasi homogenitas campuran serat tebu dan PP, keberadaan voids/porosities yang terjadi selama proses hotpress.

\section{HASIL DAN PEMBAHASAN}

\section{Evaluasi Preform}

Evaluasi prototype dimulai dari evaluasi preform yang didasarkan pada aspek fisik dalam hal keutuhan preform (bebas void dan kerobekan) serta keseragaman permukaan (halus, tanpa kerutan). Aspek fisik ini selain menentukan tampilan prototype juga mempengaruhi sifat mekanis prototype. Evaluasi pada preform juga diberikan dari catatan ketika evaluasi diberikan pada prototype. Preform awal dibuat dalam bentuk panel datar (Gambar 1a). Temuan yang didapatkan dari evaluasi adalah hadirnya void, kerutan, dinding robek, dan dinding tipis. Terjadinya kerutan karena saat dilakukan hotpress dikarenakan mould dilapisi dengan aluminium foil daripada aplikasi mould release coating yang dapat menggantikannya namun ada kendala untuk mendapatkan bahan coating dimaksud.

Temuan terkait adanya void di permukaan diperkirakan berasal dari serat tebu yang belum sepenuhnya kering. Solusi untuk mengatasinya adalah dengan penambahan waktu pengeringan dalam oven. Permasalahan terkait dengan dinding robek dan dinding tipis, hal tersebut disebabkan oleh pemberian tekanan hotpress yang dinaikkan terlalu cepat sehingga berakibat pada bahan preform tertarik oleh mould. Dinding prototype robek disebabkan oleh kurang lamanya holding time pada pemberian tekanan saat hotpress, dimana $\mathrm{PP}$ pada preform belum seluruhnya mencair sehingga robek ketika tekanan ditambah. Temuan masalah berupa dinding tipis disebabkan oleh hal yang sama untuk problem dengan dinding robek. Solusi yang diberikan untuk permasalahan dengan dinding tipis adalah dengan mengganti preform datar (Gambar 1a) menjadi preform dengan desain sama dengan prototype (Gambar $1 b)$.

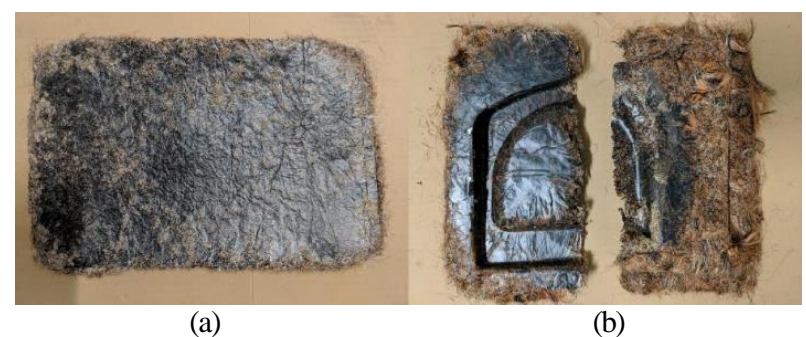

Gambar 1. Preform berbentuk flat panel (a) preform dengan desain seperti prototype (b)

\section{Evaluasi Prototype}

Setelah hasil evaluasi preform di atas ditindaklanjuti, proses kemudian dilanjutkan ke pembuatan prototype. Pada evaluasi tahap ini terdapat dua aspek utama yang diperhatikan, yaitu sifat fisik dan mekanik. Sifat fisik yang diperiksakan pada prototype dalam penelitian terdiri dari faktor visual, diskontinuitas, dan gramasitas. Sedangkan untuk sifat mekanik, yang ditinjau adalah hasil uji flexural.

\section{Faktor Visual}

Faktor visual prototype yang dimaksudkan disini adalah tampilan fisik produk, meliputi warna, tekstur, kerataan atau kehalusan permukaan minimum 
sama dengan existing material yang digunakan industri pada saat ini. Salah satu temuan faktor visual pada prototype tersebut adalah timbulnya kerutan pada permukaan prototype (Gambar 2). Kerutan tersebut timbul dikarenakan lapisan aluminium foil tertarik saat penekanan pada proses hotpress sehingga mengkerut dan diikuti oleh campuran serat tebu dan PP ketika mencair dan membeku. Seperti disampaikan sebelumnya bahwa penggunaan mould release coating akan sangat membantu.

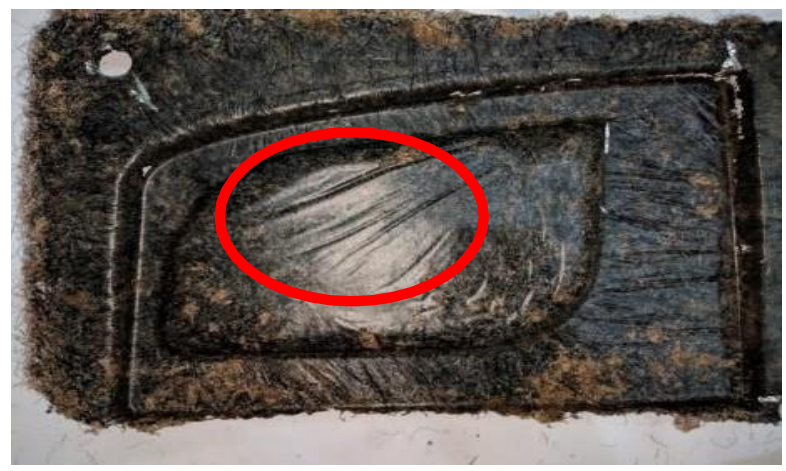

Gambar 2. Kerutan pada prototype

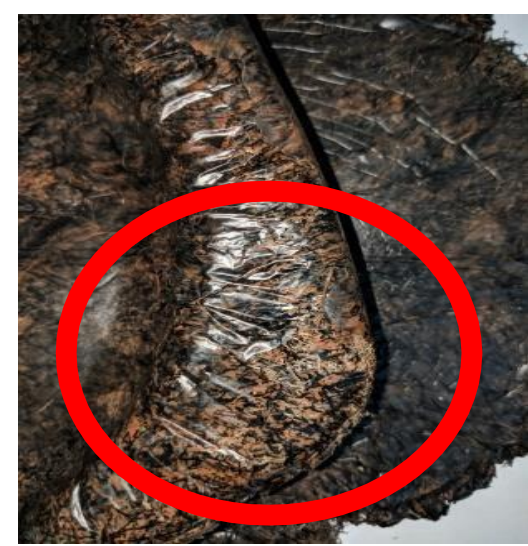

Gambar 3. Void pada prototype

\section{Diskontinuitas}

Diskontinuitas merupakan cacat yang sering terjadi dalam proses produksi. Diskontinuitas yang dimaksudkan disini adalah adanya void, dinding tipis, clustering, dan robek.

Selain masalah kerutan (Gambar 2) karena lapisan aluminum foil yang tertarik saat pemberian tekanan hotpress, ditemukan pula adanya void pada permukaan dan dalam prototype seperti ditunjukkan oleh Gambar 3. Void yang terbentuk diduga berasal dari uap air dari serat tebu yang belum sepenuhnya kering terjebak pada saat hotpress. Penyebab dinding tipis adalah karena proses penataan campuran serat tebu dan PP pada cetakan belum merata, dimana pada bagian-bagian tertentu berbeda banyaknya daripada bagian yang lain.
Faktor diskontinuitas lainnya adalah problem clustering (Gambar 4) artinya terdapat serat -serat yang berkumpul di lokasi-lokasi tertentu dalam struktur komposit. Hal ini menyebabkan struktur prototype tidak homogen sehingga bisa memberikan konsekuensi pada ketidakseragaman kekuatannya. Clustering serat tebu terjadi karena serat tebu hasil perlakuan dengan larutan $\mathrm{NaOH}$ berubah menjadi lebih kaku dan serat yang mulanya lurus menjadi keriting sehingga serat cenderung berkelompok. Solusi untuk mengatasi masalah ini dibutuhkan ekstra tenaga dan waktu untuk memisahkan serat tebu satu dengan lainnya.

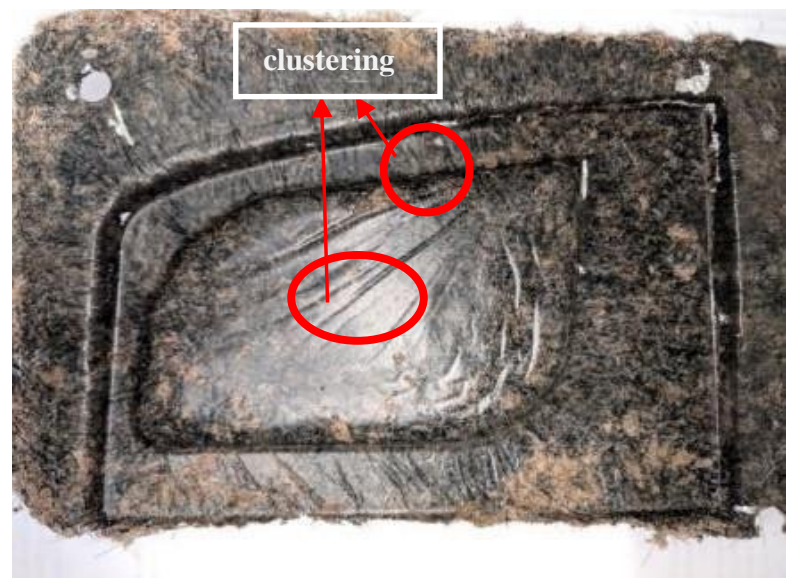

Gambar 4. Clustering di permukaan prototype

Aspek diskontinuitas lainnya yang terjadi adalah dinding tipis dan dinding robek ada prototype. Untuk kedua masalah ini diselesaikan dengan cara seperi yang disebutkan di bagian evaluasi preform. Masalah terakhir yang terjadi di prototype adalah void di dalam prototype. Void di bagian dalam ini terjadi dikarenakan masih terdapat kandungan air dalam serat tebu, air yang terdapat di dalam serat tebu ketika dipanaskan membentuk gas-gas penyebab void. Void juga disebabkan karena proses pencampuran serat tebu/PP pada preform yang kurang merata pada semua bagian preform. Hal tersebut menyebabkan adanya bagian-bagian kosong yang tidak terisi oleh PP sehingga antar PP dalam prototype terdapat jarak yang kemudian meninggalkan void atau rongga.

\section{Pengukuran Tebal}

Tabel 1 menunjukkan hasil pengukuran tebal komposit dua sampel prototype, yaitu sampel A maupun sampel B yang diukur pada lima lokasi berbeda.

Tebal komposit diukur untuk membandingkan dengan tebal produk yang dijual di pasaran. Produk yang dijual di pasaran diwakili oleh komposit woordboard yang telah disediakan oleh industri. Pengukuran tebal komposit dilakukan dengan menggunakan jangka sorong. Tebal yang diperoleh pada kedua specimen menunjukkan perbedaan variasi tebal, dimana specimen A lebih bervariasi 
daripada specimen B. Variasi tebal yang ditemui ini dimungkinkan terjadi karena penempatan jumlah campuran serat tebu/PP pada tiap lokasi pada cetakan masih dimungkinkan tidak seragam.

Tabel 1. Hasil Pengukuran Tebal

\begin{tabular}{cccccccc}
\hline & \multicolumn{6}{c}{ Tebal $(\mathrm{mm})$} \\
\cline { 2 - 8 } Spesimen & 1 & 2 & 3 & 4 & 5 & $\begin{array}{c}\text { rata- } \\
\text { rata }\end{array}$ & $\begin{array}{c}\text { Standar } \\
\text { deviasi }\end{array}$ \\
\hline $\mathrm{A}$ & 7,65 & 7,80 & 7,65 & 7,10 & 7,35 & 7,51 & 0,28 \\
$\mathrm{~B}$ & 7,20 & 7,35 & 7,35 & 7,35 & 7,35 & 7,32 & 0,06 \\
\hline
\end{tabular}

\section{Analisa Sifat Mekanis}

Selain segi estetis, kekuatan prototype juga harus memenuhi spesifikasi kekuatan yang dibutuhkan untuk aplikasi package tray mobil. Dari hasil uji flexural pada sampel yang dipotong dari prototype didapatkan kekuatan flexural terbesar adalah 7.44 MPa. Jika dibandingkan dengan sampel woodboard dari industri yang memiliki kekuatan sebesar $35.58 \mathrm{MPa}$, sampel prototype ini tergolong sangat rendah. Seperti diketahui bahwa kekuatan komposit dipengaruhi oleh empat faktor yaitu, komposisi, sifat material penyusun komposit, ikatan antara serat dengan matriks, dan yang terakhir adalah struktur. Komposisi tidak menyebabkan penurunan kekuatan material, dikarenakan rasio \% berat serat tebu/PP yang digunakan sama dengan komposisi yang digunakan pada penelitian sebelumnya [5]. Demikian pula dengan sumber material yang digunakan juga berasal dari sumber yang sama. Meskipun serat tebu yang digunakan mengalami perlakuan alkali dengan larutan $\mathrm{NaOH}$ yang berbeda konsentrasinya, yaitu $8 \%$ berat selama 1 jam pada temperatur kamar, dimana kondisi ini berbeda dengan penelitian sebelumnya menggunakan konsentrasi larutan $(20 \% \mathrm{v} / \mathrm{v})$ serta temperatur $60-70^{\circ} \mathrm{C}$ selama $4 \mathrm{jam}$, namun kondisi yang dipilih untuk penelitian ini diyakini menghasilkan kekuatan serat tebu yang lebih baik [8]. Jadi perlakuan alkali tidak menyebabkan penurunan kekuatan komposit. Dua faktor lain yang merupakan faktor pengaruh adalah ikatan antara serat tebu dengan PP serta struktur komposit. Analisa keduanya didukung melalui evaluasi struktur mikro pada penampang patahan sampel uji flexural.

Gambar 5 menunjukkan foto struktur makro pada penampang sampel uji flexural sebelum pengujian. Pada foto tersebut menampilkan beberapa temuan, yaitu:

a) Penampang yang tidak menyatu yang ditandai dengan celah kosong yang tidak diisi oleh PP atau dengan kata lain pembasahan oleh PP mengisi sela-sela serat tebu belum terjadi (tanda panah)

b) Banyaknya rongga-rongga (voids- tanda lingkaran penuh) di dalam struktur komposit yang tidak penuh terisi setelah proses hotpress. Rongga tersebut bisa disebabkan oleh gas yang terperangkap atau juga disebabkan karena proses penemparan campuran serat tebu/PP tidak seragam di dalam cetakan. Kekosongan ini menjadi titik lemah pada kekuatan bahan pada saat diuji flexural.

c) Clustering serat tebu (tanda garis elips putusputus) menunjukkan penggumpalan serat tebu setelah perlakuan alkali yang belum terpisah dengan baik. Hal tersebut menimbulkan ketidak seragaman struktur dan sifat komposit yang dihasilkan.

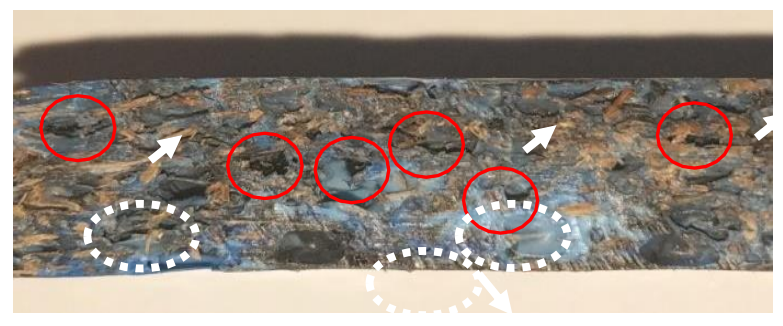

Gambar 5. Foto makro penampang sampel uji flexural

\section{Evaluasi Struktur Mikro}

Studi struktur mikro dilakukan pada penampang melintang sampel hasil uji flexural menggunakan SEM. Hasil foto SEM ditunjukkan pada Gambar 6 dan 7.

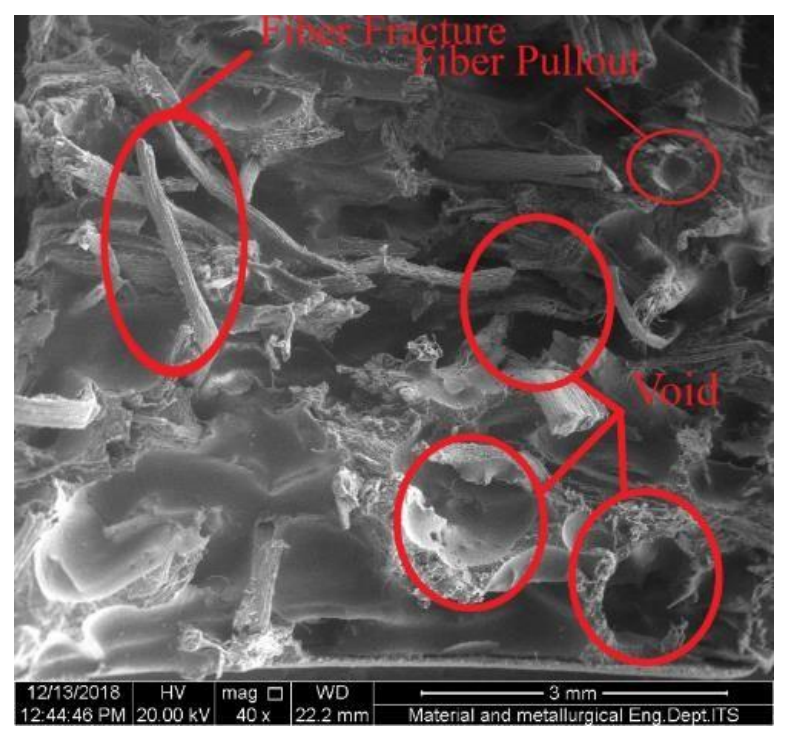

Gambar 6. Foto mikro pada penampang melintang permukaan patahan

Gambar 6 menunjukkan adanya area void yang tidak terisi oleh campuran serat tebu/PP serta void karena fiber pull-out. Adanya fiber pull-out mengkonfirmasi rendahnya kekuatan ikatan antara serat tebu-PP. Dengan demikian tegangan yang terjadi akan menjadi beban dari matriks PP yang terjadi melalui matrix yielding. Hal inilah yang menyebabkan hasil kekuatan flexural yang rendah. Pada gambar 7, clustering serat tebu teridentifikasi pada struktur sampel komposit. Hal ini menyebabkan ketidakhomogenan struktur dan berakibat bervariasinya kekuatan komposit. 


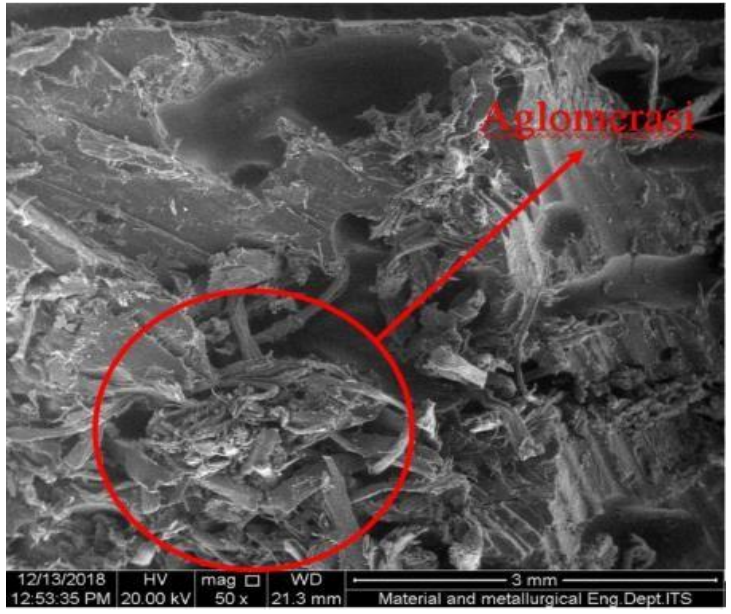

Gambar 7. Foto mikro pada permukaan atas sampel

\section{KESIMPULAN}

Evaluasi pembuatan prototype dengan proses hotpress ini banyak dipengaruhi oleh proses handling bahan baku dalam hal ini adalah serat tebu, proses pencampuran serat tebu dengan PP, serta memastikan bahwa penempatan campuran pada cetakan dengan jumlah yang seragam. Bila hal-hal mendasar tersebut telah dipastikan dapat teratasi ketika dilakukan secara manual (perlu prosedur baku yang diperbaiki terus menerus) maka dengan pemahaman dan pengaturan kombinasi parameter waktu dan tekanan yang pas pada tahap proses hotpress, dimungkinkan untuk mendapatkan prototype yang sesuai dengan spesifikasi industri sesuai dengan temuan ketika dikerjakan dalam bentuk sampel melalui penelitian sebelumnya.

\section{UCAPAN TERIMAKASIH}

Terimakasih kepada Pabrik Gula Candi Baru Sidoarjo atas pemberian ampas tebu serta ucapan terimakasih yang sama kepada PT Classic Prima Carpet Industries atas pemberian serat PP untuk digunakan sebagai bahan penelitian. Kami juga menyampaikan apresiasi atas bantuan Sdr. Raga dari PT. Agrindo terkait dengan setup mesin hotpress.

\section{DAFTAR PUSTAKA}

[1]. Pilla, S. and Lu, Y.C.,2015, Biocomposites in Automotive Applications, SAE International, Warrendale, pp. 1-2.

[2]. Suddell, B. C. and Evans, W. J., 2005, Natural Fiber Composites in Automotive Applications, Natural Fibers, Biopolymers, and Biocomposites edited by A.K. Mohanty, M. Misra and L.T . Drzal, CRC Press.

[3]. Mwaikambo, L.Y. and Ansell, M.P., 2006, Mechanical Properties of Alkali Treated Plant Fibres and Their Potential as Reinforcement Materials II, J Mater Sci, 41,8, pp 2497-2508.

[4]. Anggono, J., Sugondo, S., Sewucipto, S., Purwaningsih, H., \& Henrico, S., 2017, The use of sugarcane bagasse in PP matrix composites: A comparative study of bagasse treatment using calcium hydroxide and sodium hydroxide on composite strength. AIP Conference Proceedings, 1788,1, pp 030055.

[5]. Anggono, J., Suwandi S., Rassy Alim, Hariyati Purwaningsih, Aria Wibawa, 2018, Performance and Evaluation of Low Cost Sugarcane Bagasse - Polypropylene Biocomposites as Candidate Material for Automotive Parcel Tray. Material Science Forum 923,40, pp 40-46.

[6]. Anggono, J., Farkas, Á.E., Bartos A., Móczó, J., Purwaningsih H., and Pukánszky, B, 2019, Deformation and Failure of Sugarcane Bagasse Reinforced PP, Eur. Pol. J, 112, 153-160.

[7]. Direktorat Jenderal Perkebunan Kementerian Pertanian (2020). Buku Tebu 2018- 2020. https://drive.google.com/file/d/146gs_KoWGoQ B_yX8OURJc046AjZHAEFH/view

[8]. Bartos A., Anggono, J., Farkas, Á.E., Kun, D., Soetaredjo, F.E., Móczó, J., Antoni, Purwaningsih H., and Pukánszky, B, 2020, Alkali Treatment of Lignocellulosic Fibers Extracted from Sugarcane Bagasse: Composition, Structure, Properties, Polymer Testing 88, 106549. https://doi.org/10.1016/j.polymertesting.2020.1 06549 